\title{
THE DEVELOPMENT OF CARD MEDIA WITH SCIENTIFIC APPROACH ON JUNIOR HIGH SCHOOL OF MATHEMATICS LESSON
}

\author{
Erik Kuswanto, Imam Turmudi, Moh. Mahfud Effendi \\ Study Program of Mathematics, Faculty of Teacher and Trainning University of \\ Muhammadiyah Malang \\ forerik99@gmail.com
}

\begin{abstract}
The goal of the research to describe of development of card media with scientific approach on mathematics lesson, and show the practical and effectivity of card media with scientific approach. The research's model use Borg and Gall model. The steps of the research are : analyze of potential and problem, the collect of data, product design, design validation and revision of design. Trying of test was conducted to know the effectivity of card media. The instrument use observation sheet, questionnaire, and observation sheet of test's trying. The design of validation's result show that media is valid and it can apply on the teaching learning. The result of test's trying show that card media is practical to use as mathematics learning's media. Beside that, the student classical of total's percentage after do the test show that media is effective to use as teaching learning.

Keyword : Development of Card Media, Scientific Approach, The Practical and Effectivity
\end{abstract}

\section{INTRODUCTION}

Student's achievement to understand of problem is definited by student's interest to teacher. The one of student's interest by media using in teaching learning (Muchith, 2008: 37). The observation's result of mathematics learning's activity in junior high school show that, the card media is less to use in teaching learning. Beside that, learning's process is still using books and directive's book. Student learned to think concrete, so that student have motivation to study. It means that, learning media is important to use in mathematics learning.

Hamalik (on Arsyat, 2011: 15) explain that learning media on the teaching learning process can make student's motivation be increasing. Mathematics learning's process can make student more active on their mental or physical with scientific approach. On education's rule Number 68 Year 2013 about standart of education's process which education rule with scientific approach. So that, mathematics learning need scientific approach on learning process. Scientific approach can increase student's attitude, knowledge and skill, including observation, thinking process and trying to 
solve a problem (Komara, 2014: 88). Scientific approach can make by card media. Card media is visual media which has information to give a student. The form of nformation are picture and text (Arsyat, 2011: 119).

The research which do Nur faizah (2013: 64) about card media on mathematics learning process explain that card media can increase student's motivation and make student more active. Rahayu (2013: 5) found that card media on mathematics learning can help student to understand a problem.

\section{THE METHOD OF THE RESEARCH}

The developing of card media with scientific approach use Borg and Gall model. The reasearch to produce a product and make test about product's effectivity. The research and the develop has a steps : (1) analyze of problem; (2) collect a data; (3) product design; (4) validate of problem; (5) revise of design; (6) test a product; (7) revise a product (Sugiono, 2015: 409).

The instrument's research use sheet of validation's media, and sheet of observation's test. Sheet of validation's media used to know the valid of card media. Questionnaire and sheet of observation's test used to measure of cars media's practical. The level of card media effectivity can be seen by student's clasical achieve after follow the learning process with card media. The card media test was conducted of twentythree student class VII of junior high school of Muhammadiyah Malang.

\section{THE RESULT AND THE DISCUSSION}

The result of analysis a problem that is card media is not focused on student. It means that, need a card media which can make student's motivation on learning. The card media is scientific approach. On the collecting of data step get a matter of social arithmatic with content of competence, base of competence, and learning indicators. The data is for design of media. The content of competence and base of competence on the matter social arithmatic can be seen by table 1 . 
Table 1 The content of competence and base of competence on the matter social arithmatc

\begin{tabular}{l} 
The content of competence \\
\hline The base of competence \\
making, modificating) and the abstract with social arithmatic (selling, buying, \\
aspect (writting, reading, counting, drawing discount, percentage, etc). \\
and arranging) which similarity with theory \\
of the study
\end{tabular}

Table 2 The indicator of social arithmetic

\section{Learning indicators}

4.11.1. Student can decide a selling price, buying price, profit, loss, profit percentage, and loss persentase

4.11.2. student can decide a singular price, tax and discount

4.11.3. Student can decide a gross, tare and net

Design process do three steps : (1) make a format; (2) make a design; (3) make a media. Design process do by make a design with coreldraw. The design's result of card media contain of three type and different matter. The first type of card contain about gross, tara, gross percentage, tara percentage, selling price and buying price. The second type of card contain about discount and tax. The third type contain about gross, tare and net. On every card contain five characteristic of scientific approach with instruction.

The first card with observation characteristic, can be seen on picture 1 .
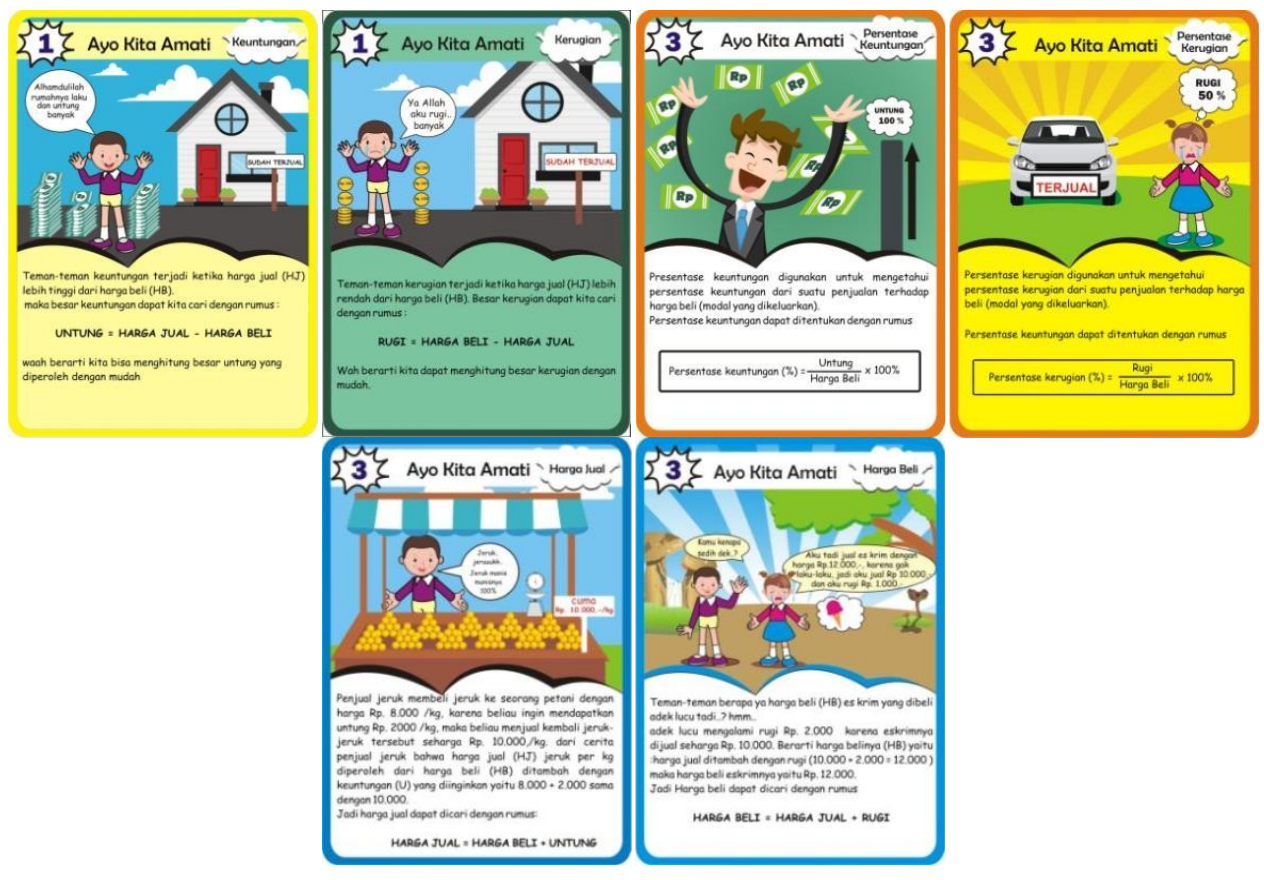

Picture 1 : The result of card media design 
The second card with observation characteristic, can be seen on picture 2
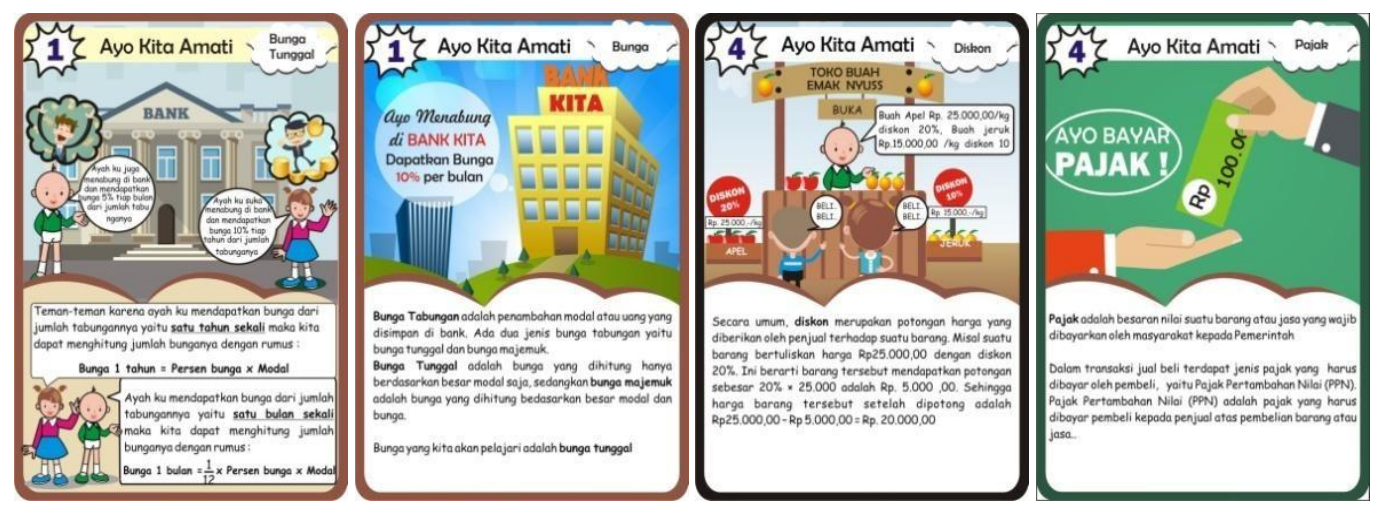

Picture 2 : The result of card media design

The third card with observation characteristic, can be seen on picture 3 .
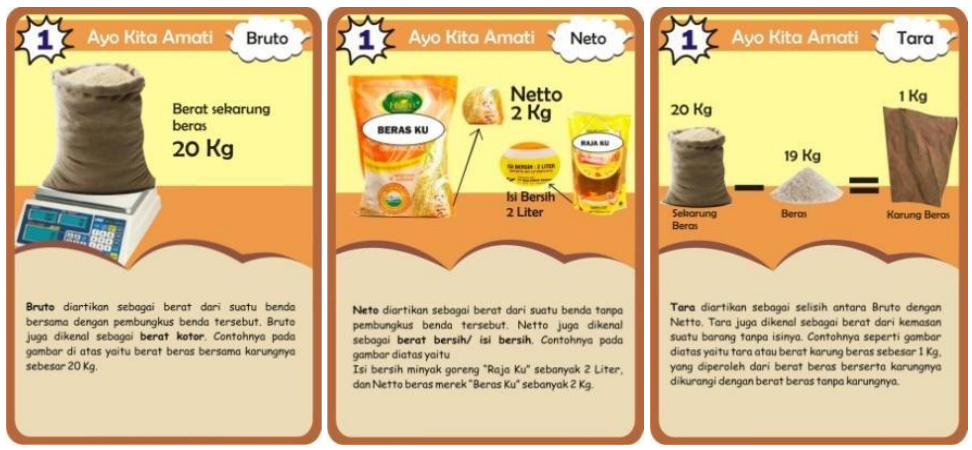

Picture 3: The result of card media design

Picture 1 has information about gross percentage, and tara percentage. Picture 2 has information about discount and tax. Picture 3 has information about gross, tara and net. Every card has characteristic which be picture. The result of card media design of asking characteristic, can be seen on picture 4 .
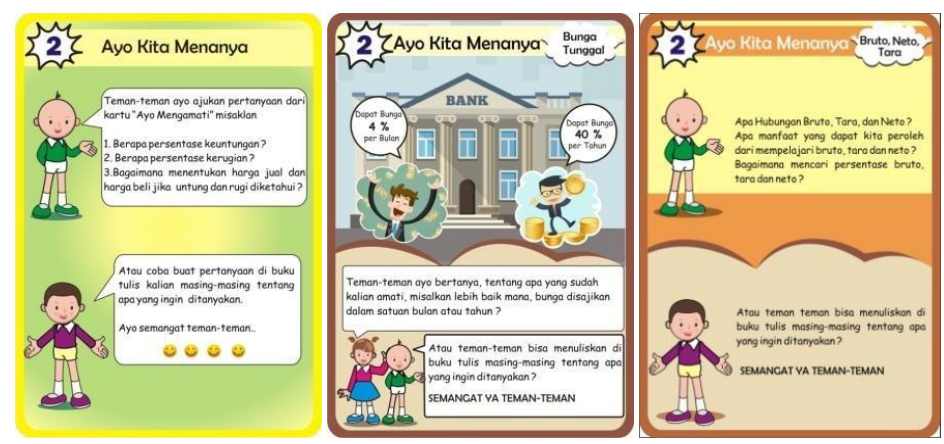

Picture 4 : The result of card media design

Picture 4 contain an example about the matter which student get before. 
The result of card media design with scientific approch by thinking characteristic, can be seen on picture 5 .
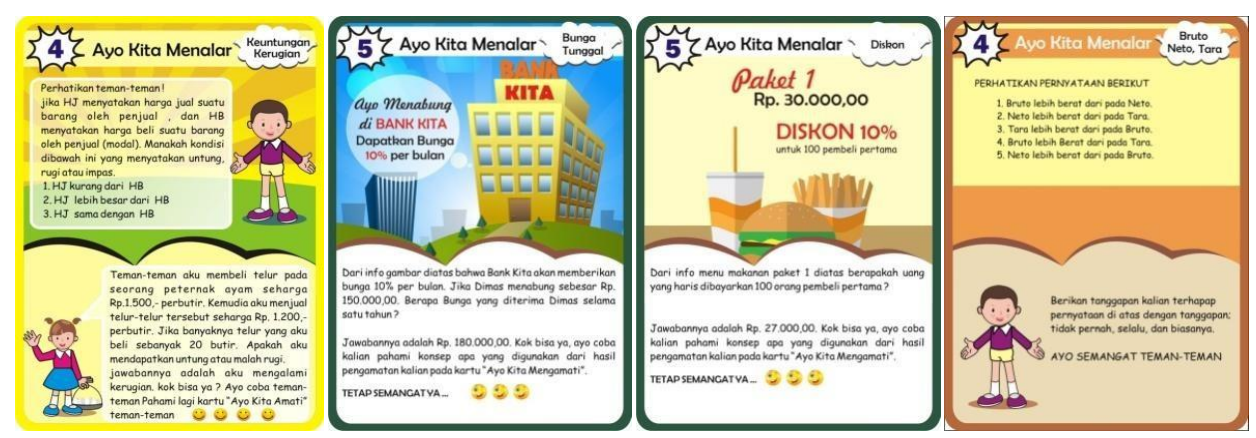

Picture 5 : The result of card media design

Picture 5 need thinking activity by student to give solution about problem. The problem which give from the card is about thinking characteristic. After student understand the problem, student will try a card with trying activity.

The result of card media by trying characteristic, can be seen on picture 6 .
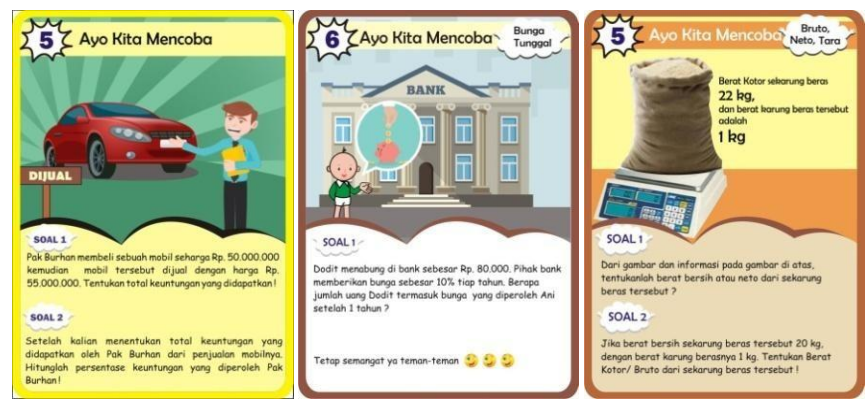

Picture 6 : The result of card media design

Picture 6 contain a problem which must do student with their thinking process which has explain on observation characteristic. After that, student do communication's activity with card by communication activity. The result of card media design of communication characteristic, can be seen on picture 7 .
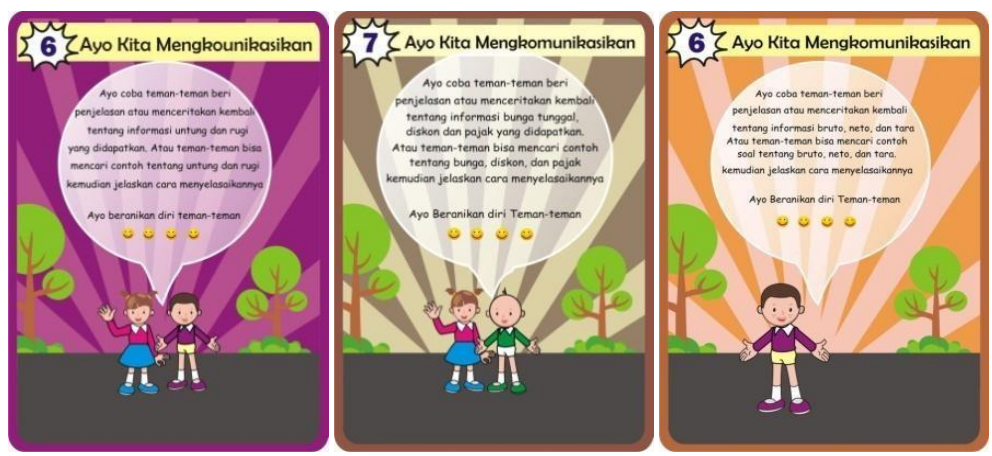

Picture 7 : The result of card media design 
Picture 7 contain about the way to communication student's ability which student is got by observation, asking, thinking, and trying activity. The result of card media design also give the instructure, it can be seen on picture 8 .
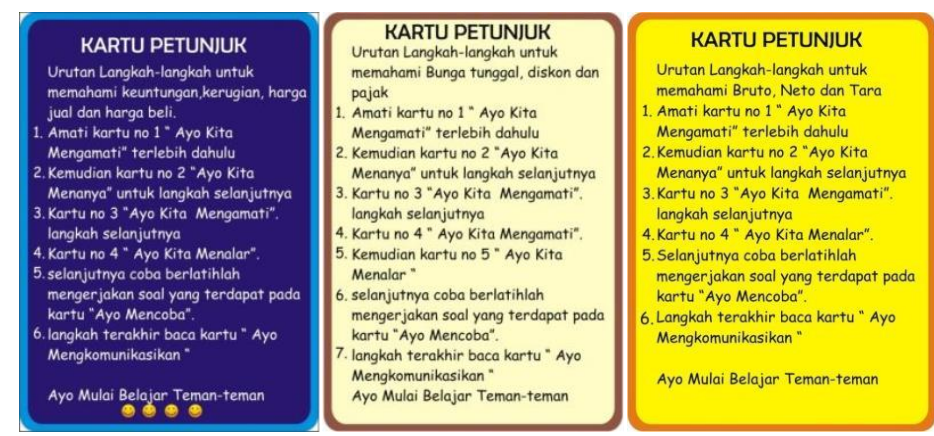

Picture 8 : The result of card media design with the instructure

Picture 8 contain the step of card media using with scientific approach. The result of card media design on back part can be seen on picture 8 .
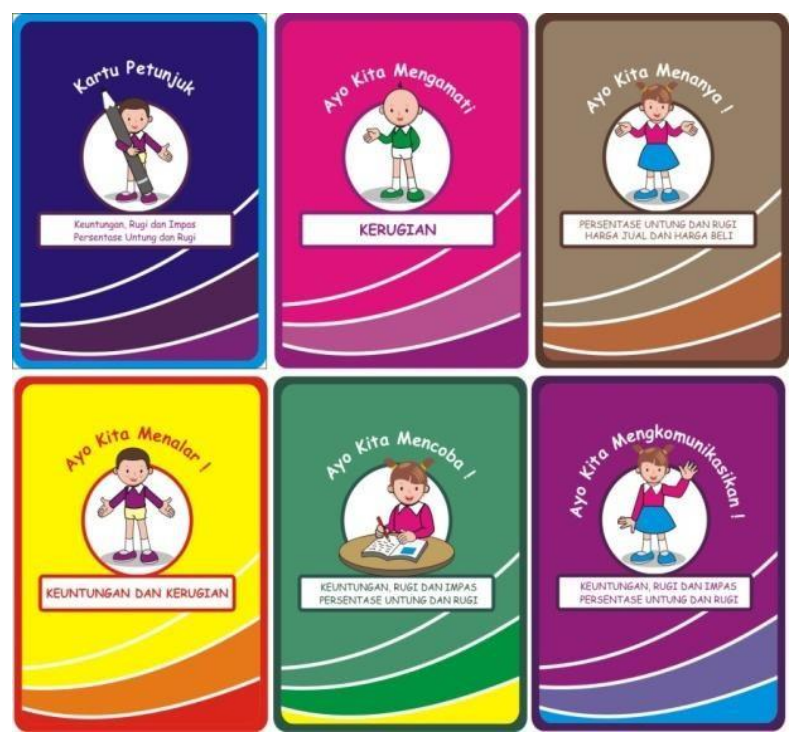

Picture 9 : The result of card media design on back part

Picture 9 is the result of card media design on back part, the part contain with sub material which will be learned by scientific approach. On back part there is interest picture with scientific approach. 


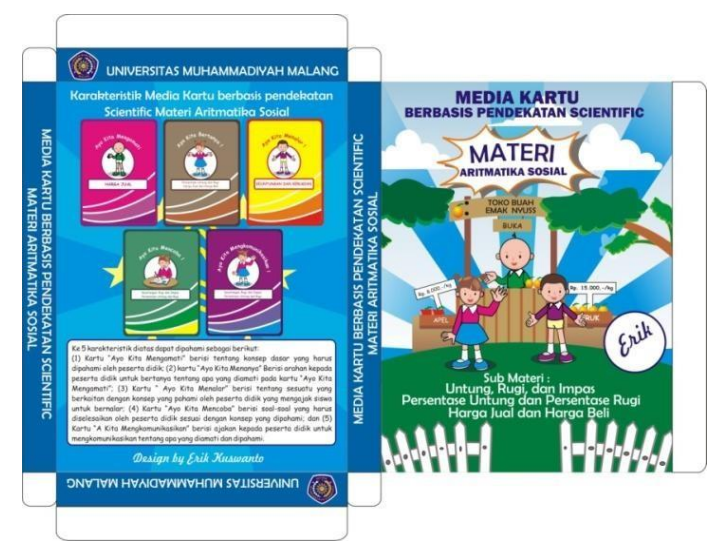

Picture 10 : The result of card media design

Picture 10 is the result of card media design which will develop. The card media has four side, they are front part, back part, left and right part, and up and down part. Front part contain with theme of card, material, picture, etc. Back part contain with scientific approach which be on back part of card. Left and right part contain with theme of card, meanwhile up and down part contain with symbol of University of Muhammadiyah Malang.

The result of card media will be validation by media specialist to knowing the level of card's validation with use validation's sheet. The result of media get score 3,97 which show that card media be on valid criteria. The card can be tested to student. The result of card media design, according media specialist can be seen on picture 11 .
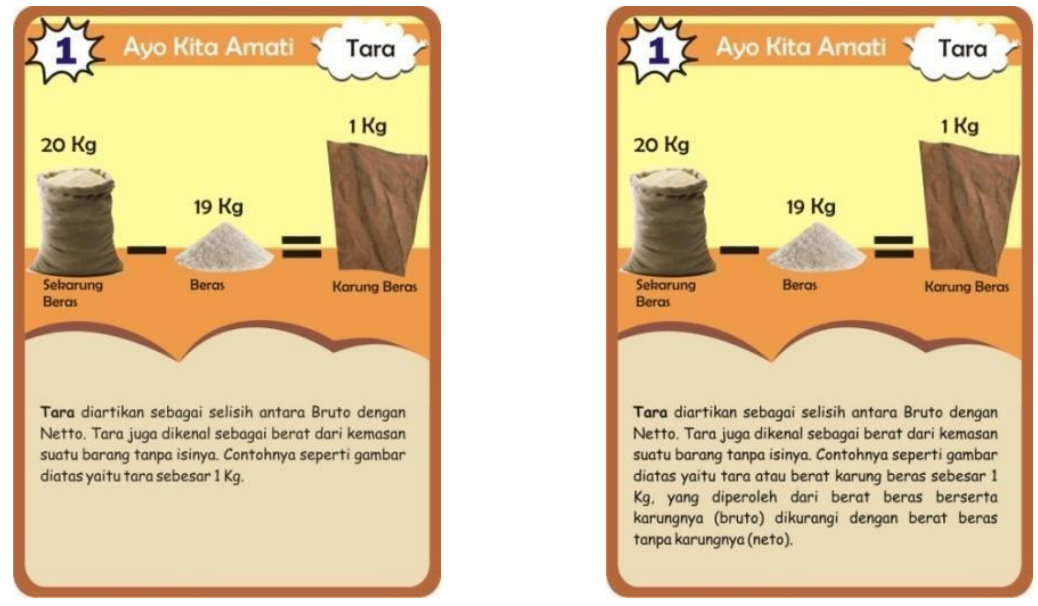

Picture 11 : Card media in before and after do revision

Picture 11 is the media part which need repair about the gross, tara and netto. After revision process, the media can be tested to student. The test process to knowing the effectivity of card media. The test's process was conducted on March 29 Year 
2017 with the subject is twentythree student on class VII of junior high school. The test's process do one time and trying test's process make a group, on every group there are 2 or 3 student. The trying test's process is done by steps of research's introduction, making groups, give validation sheet to teacher, collect of questionnaire.

The result of card media's effectivity with student's questionnaire get score 3,22 and 3,00. Both of score show that card media be on practical criteria. Then, the effectivity of card media is showed by student's classical achieve about $87 \%$. The score of classical achieve be on effective criteria. When the process of product test, student did not found a mistaken concept. So that, on the last step did not done.

\section{CONCLUSION}

The develop of card media with scientific approach include the steps of (1) analysis of problem; (2) collect of data; (3) product design; (4) validation of design; (5) revision of design; (6) product test; (7) revision product. The result of media show that media is valid and effective with use scientific approach, it means that card media with scientific approach is practical to used on mathematics learning.

\section{REFERENCES}

Arsyad, Azhar. 2011. Learning Method. Jakarta : PT Raja Grafindo Persada.

Isnaeni, Nur Faizah. 2013. Use of Numeric Card Media To Increase Motivation and Learning Outcomes of Roman Numbers Material to Grade 4 Students of Primary School of Debong Tengah 1 Tegal. Available (Online), (http://lib.unnes.ac.id), accessed on January 20, 2017.

Komara, Endang. 2014. Learning and Interactive Learning. Bandung: PT. Refika Editama.

Muchith, Saekhan . 2008. Contextual Learning. Semarang: Rasail Media Group. Rahayu, Tutik. 2013. Improving Learning Outcomes of Integral Material Using Colored Picture Cards In Grade IV Elementary School Students. Journal of Primary School Teacher Education Research, 1 (2). (Online), (http://jurnalmahasiswa.unesa.ac.id), accessed on January 20, 2017.

Sugiono. 2015. Educational Research Methods (Quantitative Approach, Qualitative, and $R$ $\& D)$. Bandung : Alfabetha. 